Univerzitet u Beogradu
Poljoprivredni fakultet
Institut za poljoprivrednu tehniku
Naučni časopis
POLJOPRIVREDNA TEHNIKA
Godina XLV
Broj 4, 2020.
Strane: $1-7$

\title{
THE IMPORTANCE OF INTRODUCING A DIRECT FOOD DISTRIBUTION MANUFACTURED BY AGRICULTURAL PRODUCTION IN A SINGLE ECONOMY
}

\author{
Ivan Arnautović ${ }^{1}$, Maja Jokić ${ }^{2}$ Bogdan Laban³ ${ }^{3}$ Dragana Popović, \\ Slobodan Popović* ${ }^{5}$, Sanda Nastić ${ }^{6}$ \\ ${ }^{I}$ High School of Entrepreneurship, Majke Jevrosime 15, 11000 Beograd, R. Serbia \\ ${ }^{2}$ Faculty of Technical Sciences, University of Novi Sad \\ Trg Dositeja Obradovica 6, 21000 Novi Sad,R. Serbia \\ ${ }^{3}$ City administration of the City Subotica, Trg Slobode 1, 24000 Subotica,R.Serbia \\ ${ }^{4}$ Economic Faculty Subotica, 24000 Subotica, R.Serbia \\ ${ }^{5}$ Internal Auditor, Public utility company "Gradsko Zelenilo Novi Sad \\ Temerinski put bb, 21000, Novi Sad, Serbia \\ ${ }^{6}$ JKP Vodovod i Kanalizacija, Masarikova 17, 21000 Novi Sad, R.Serbia
}

Summary: The agricultural sector should be organized in such a way that agricultural products that create highways in the form of production and sale of food should be supplied through direct food supply distribution chains. In addition, the food distribution system should target food produced and sold locally, which has gained increasing importance over the last three decades. Thus, agrarian observation enables fierce market competition, high distribution and logistics costs, as well as small individual size of shipments, etc. Using agricultural business modeling and design approaches requires new aspects of innovative logistics and modern information and communication technologies. All this makes it possible to evaluate and evaluate different ways of distributing food. This paper draws attention to the importance of the direct model as a channel of distribution and access in the organization of agriculture as an activity. After that, it is possible to make precise analyzes that can be used to refine the model of business processes with the formation of various ways of food distribution.

Key words: short food supply chain; distribution; sustainability; information and communication technology; business process modelling

*Corresponding author: Slobodan Popović, email: slobodan.popovic49@gmail.com 


\section{INTRODUCTION}

The supply of food that is the product of agricultural activity should respect the principles of sustainability (economic, environmental and social) and provide progressive opportunities for them. The basis of modeling that will enable the adoption of such a way of managing agriculture that will be in line with the economic strengthening of the country.

Modeling food management and its distribution should take into account the network through which products move from the point of production to the consumer, with a minimum number of intermediaries.

This leads to a decrease in the number of road users, a decrease in the brokerage fee, with easier control over the sale price, but also the existence has a positive impact on the employment rate.

In addition to the directly visible impact, there is also the impact of strengthening the sense of power of the agricultural sector towards a sustainable society and influencing the social development of the region while preserving local communities and social justice, especially in rural areas. Finally, there is an impact on environmental criteria.

Thus the concept of creation of agricultural observation [1], [2], [3], [4], [5] and products of agriculture in the form of food [6], [7], [8], [9], [10 ] which is heterogeneous distribution methods [11], [12], [13] and which [14] is delivered to a large number of consumers [15].

\section{THE IMPORTANCE OF AGRICULTURAL MANAGEMENT IN THE PROCESS OF FOOD DISTRIBUTION}

Management of agriculture should be seen as management associated with the distribution of food, as well as the existence of a justification for the costs of the implementation of logistics activities, while respecting regulated and complicated legal provisions.

Accordingly, modern management respects contemporary logistical trends (digitization, cost reduction, improving flexibility and reactivity to customer demand, etc.), while respecting the specific context of the distribution of locally produced food in the sovereign market.

Technological advances in information and communication technologies should be accompanied by appropriate business models as a reflection of innovative logistics strategies and changes in the logistics management paradigm that can be applied in agriculture, that is, in food production and food distribution in the territory of a country.

The basis for this study is finding an effective solution for the state-level food distribution system, that is, a food distribution system that can be implemented in the Republic of Serbia. 
The focus of such modeling in the work has been put by the author on direct supply as a distribution channel.

\section{A MODEL THAT TAKES INTO ACCOUNT THE FACTORS AFFECTING CUSTOMERS IN THE OBSERVED DISTRIBUTION SYSTEM}

Finding a practical model of behavior requires the application of a number of factors that influence the formation of a distribution chain. In this paper, the authors present the following important factors of influence on the customer as key points of the distribution

system.

The presentation is given in Figure \# 1 by the author and presents possible ways of organizing and influencing the customer as a key category of observation, respectively, by categorizing the impact on customers that are a key category of observation in the food distribution system in the Republic of Serbia.

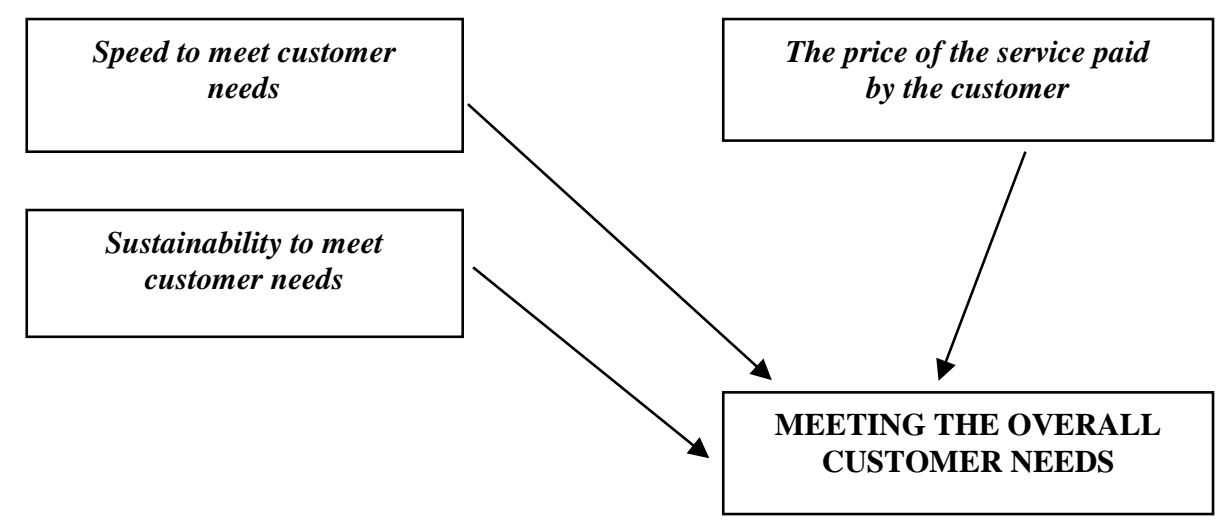

Fig. 1. Meeting the needs of customers who are the focus of interest of food distribution companies

\section{INNOVATIVE LOGISTICS SOLUTIONS AS A PRODUCT OF THE SUPPLY CHAIN MANAGEMENT STRATEGY}

When defining a supply chain management strategy, companies are confronted with a number of limiting factors that result from the changes that are happening in the global economic environment.

These changes, in the form of new trends, affect the business strategy, which directly depends on the choice of strategy to be applied by the companies dealing with the organization of food distribution in a particular market.

The authors illustrate possible solutions that will implement innovations in the logistics approach to food distribution through the illustrations in Figure 1. 


\section{DIRECT SUPPLY - SHORT SUPPLY CHAIN}

A short food supply chain, commonly referred to in the literature as a direct or local food supply chain, can be identified by two basic characteristics: A direct food supply means "production, processing, sale and consumption of food takes place in a relatively small geographical area (territory) the number of intermediaries (or intermediaries) in the chain is minimal '.

Such supply is defined as a "short supply chain", when short distances or only a few intermediaries exist between producers and consumers.

This management aims to reduce the number of intermediaries in their economic endeavor to make the manufacturer make a greater share of the profits than the production in which he or she performs economic.

\section{BASIC CHARACTERISTICS OF DIRECT FOOD SUPPLY CHANNELS}

There are numerous peculiarities related to the direct food supply channels in the logistics process and this way of observing the organization.

The authors point out the most important three factors that should be taken into account in the process of considering the direct way of food supply in the Republic of Serbia.

The essential characteristics of the outlined supply model would be:

1. Direct communication between producer and consumer,

2. Local existence in the local market

3. Selling in addition to local buyers.

\section{RESPECT FOR THE FOOD DISTRIBUTION CHANNEL ENVIRONMENT}

The authors provide a possible overview that points to the observation and importance of the environment from the impact on the consumer as a target category, which is the focus of all movements in the form of tracking the product from the moment of creation to the moment when it is offered for sale.

The authors illustrate the importance and the impact on the consumer of the environment by presenting the number 2 image.

This implies that the environment influences changes in business and competitive strategies, which is ultimately the result of changes in strategy that will be implemented by new and innovative logistics in the distribution of food in the country by companies primarily engaged in agricultural business.

\section{A MODEL THAT ENABLES SHORT DISTRIBUTION OF AGRICULTURAL PRODUCTS}

A model that includes agricultural operators as well as consumers on the other hand who is the focus of research and allows for the short distribution of agricultural products is shown in Fig. 1 by the author. 


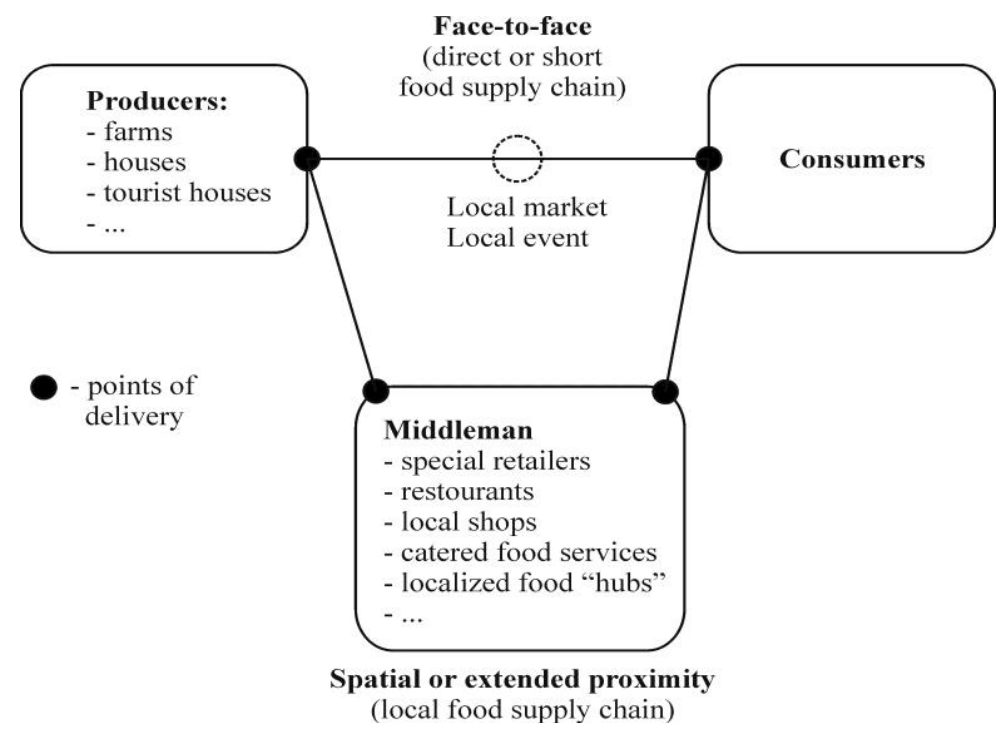

Fig. 2. Model of short distribution of feed in the Repbulic of Serbia

\section{DISCUSSIONS}

The formation of a possible sustainable model of an efficient logistics system in agriculture is crucial for the development of a logistical food distribution system in a country's economy.

In this paper, the authors draw attention to the existence of a direct model by which applications can be implemented in the real business of a large number of individual entities.

The authors have presented models by which it is possible to create the development and improvement of logistical resources and competencies of food producers.

This can, with the use of logistical capacities, make a real functioning of the food distribution system and provide the satisfaction of basic and desired customer needs.

\section{CONCLUSION}

In this paper, the authors draw attention to the use of a possible applicable food distribution model in a country that seeks to meet the needs of customers to purchase food under acceptable general conditions. 
The authors provided a direct acceptable model of food supply. This model may be the basis for future research into those that aim to engage in direct food distribution with some of the innovations in food distribution and customer satisfaction.

However, there are limitations to the application of the model. Let's just point out: a small concentration that can mean delivering small amounts of food in this way of food distribution.

\section{REFERENCES}

[1] Williams, C. 2010. Principi menadžmenta, Data Status, Beograd.

[2]Cantino, V. 2009. Korporativno uptravjanje, merenje performansi i normativna usaglašenost sistema internih kontrola, Beograd, Data Status.

[3] Engelseth P. 2016. Developing exchange in short local foods supply chains. Int. J. Food System Dynamics, 7(3): 229-242.

[4] Stahlbrand L. 2016. Short food supply chains and "infrastructure of the middle": The role of university food procurement in sustainability transition. Wilfrid Laurier University, Waterloo, Canada.

[5] Martikainen A, Niemi P, Pekkanen P. 2014. Developing a service offering for a logistical service provider-case of local food supply chain. Int. J. Production Economics. 157: 318-326.

[6] Kull TJ, Chae S, Choi T. 2017. The Future of Supply Chain Management. Supply Chain 24/7.

[7] Casadesus-Masanell R, Feng Z. 2013. Business model innovation and competitive imitation: the case of sponsor-based business models. Strategic Management Journal, 34(4): 464-482.

[8] Janssen GR, de Man AP, Quak HJ. 2015. Strategic business models for cross-chain control centers (4C). In: de Kok T, van Dalen J, van Hillegersberg J. (eds.) Cross-chain collaboration in the fast moving consumer goods supply chain. Eindhoven University of Technology, Eindhoven, Rotterdam, Enschede, Netherland.

[9] Popović, S., Ugrinović, M., Tomašević, S. 2015. Management of Agricultural Enterprises by Means of Fair Financial Reporting in Accordance with International Standards of the Finance and Accounting Reporting, CDQM, Number 3: 24-30.

[10] Ribeiro C, Fernandes J, Lourenco A, Borbinha J, Pereira J. 2012. Using serious games to teach business process modeling and simulation. In: Proceedings of the 2012 World Congress in Computer Science, Computer Engineering, and Applied Computing, 16-19, Las Vegas, Nevada, USA.

[11] Verdouw CN, Beulens AJM, Trienekens JH, Wolfert S. 2010. Business process modelling in demand-driven agri-food supply chains. In: Proceedings in System Dynamics and Innovation in Food Network, 307-322.

[12] Engelseth P, Hogset H. 2016. Adapting supply chain management for local foods logistics. Int. J. Food System Dynamics, 7(3): 143-160.

[13] Northouse, P. (2008). Liderstvo. Beograd, : Data Status.

[14] Rodriguez, M., Miguel, Sanchez, L., Cejudo, E. \& Antonio, C. 2019. Variety in local development strategies and employment: LEADER programme in Andalusia. Agric. Econ. - Czech, 65: 43-50. 
[15] Popović, S., Tošković, J., Majstorović, A., Brkanlić, S., Katić, A. 2015. The importance of continuous audit of financial statements of the company of countries joining the EU, Annals of the „Constantin Brâncuşi” University of Târgu Jiu, Economy Series, Special Issue, 241-246.

\title{
ZNAČAJ UVOĐENJA DIREKTNOG KANALA DISTRIBUCIJE HRANE PROIZVEDENE OD STRANE POLJOPRIVREDNE PROIZVODNJE U JEDNOJ EKONOMIJI
}

\author{
Ivan Arnautović ${ }^{1}$, Maja Jokić ${ }^{2}$ Bogdan Laban ${ }^{3}$, Dragana Popović ${ }^{4}$, \\ Slobodan Popović ${ }^{5}$, Sanda Nastić \\ ${ }^{1}$ Visoka škola za preduzetništvo, Majke Jevrosime 15, 11000 Beograd, R.Srbija \\ ${ }^{2}$ Univerzitet u Novom Sadu, Fakultet Tehničkih nauka, 21000 Novi Sad, R.Srbija \\ ${ }^{3}$ Gradska upava Grada Subotice, Trg Slobode 1, 24000 Subotica, R.Srbija, \\ ${ }^{4}$ Economski Fakultet Subotica, 24000 Subotica, R.Srbija \\ ${ }^{5}$ Interni revizor, JKP Gradsko Zelenilo, Temerinski put bb, 1000 Novi Sad, R.Srbija \\ ${ }^{6} J K P$ Vodovod i kanalizacija, Masarikova 17, 21000 Novi Sad, R.Srbija
}

Sažetak: Poljoprivredni sektor treba da se organizuje tako da produkti poljoprivredne delatnosti koji stvaraju autpute $\mathrm{u}$ vidu proizvodnje i prodaje hrane treba da se organizuju putem korištenja direktnih lanaca distribucije snabdevanja hrane. Osim toga, sistem distribucije hrane treba da bude usmeren na hranu koja se proizvodi i prodaje lokalno, a koja dobija sve veći značaj u poslednje tri decenije. Tako posmatranje agrara omogućava oštru tržišnu konkurenciju, postojanje visokih troškova distribucije i logistike, kao i malu pojedinačnu veličinu pošiljki itd. Koristeći pristupe modeliranja i projektovanja poslovanja od poljoprivrednih preduzeća se zahteva primena novih aspekata inovativnog načina logistike koji pretpostavljaju primenu savremenih informacionih i komunikacionih tehnologija. Sve to omogućava ocenu i procenu različitih načina distribucije hrane. Ovaj rad, skreće pažnju na značaj korištenja modela direktnog kanala distribucije hrane. Nakon toga, moguće je sačiniti precizne analize pomoću kojih će se moći usavršiti prikazani modela distribucije hrane.

Ključne reči: kratak lanac snabdevanja hranom; distribucija; održivost; informaciono-komunikaciona tehnologija; modeliranje poslovnih procesa

Prijavljen:

Submitted:

04.05.2020.

Ispravljen:

Revised:

13.11.2020.

Prihvaćen:

Accepted:

27.11.2020. 